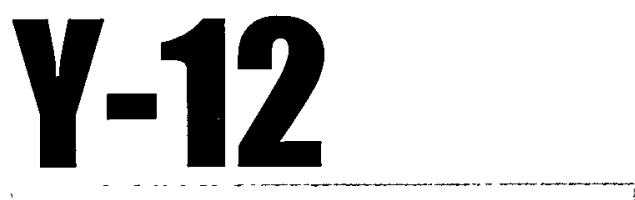

\section{OAK RIDGE \\ $Y-12$ \\ PLANT}

LOCKMEE D MARTINT

MANAGED BY

LOCKHEED MARTIN ENERGY SYSTEMS, INC.

FOR THE UNITED STATES

DEPARTMENT OF ENERGY

UCN-13672 (2 11-97)

\section{Y-12 PLANT GROUNDWATER PROTECTION PROGRAM GROUNDWATER AND SURFACE WATER SAMPLING AND ANALYSIS PLAN \\ FOR CALENDAR YEAR 2000}

Prepared by
AJA TECHNICAL SERVICES, INC. Under Subcontract 70Y-MVM64V

Reptember 1999 RECEIVED
NOV 041999

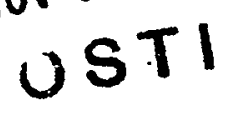

for the

Environmental Compliance Department

Environment, Safety, and Health Organization Oak Ridge Y-12 Plant

Oak Ridge, Tennessee 37831

\section{Managed by}

LOCKHEED MARTIN ENERGY SYSTEMS, INC. for the U.S. DEPARTMENT OF ENERGY under contract No. DE-AC05-84OR21400 


\section{DISCLAIMER}

This report was prepared as an account of work sponsored by an agency of the United States Government. Neither the United States Government nor any agency thereof, nor any of their employees, makes any warranty, express or implied, or assumes any legal liability or responsibility for the accuracy, completeness, or usefulness of any information, apparatus, product, or process disclosed, or represents that its use would not infringe privately owned rights. Reference herein to any specific commercial product, process, or service by trade name, trademark, manufacturer, or otherwise, does not necessarily constitute or imply its endorsement, recommendation, or favoring by the United States Government or any agency thereof. The views and opinions of authors expressed herein do not necessarily state or reflect those of the United States Government or any agency thereof. 


\section{DISCLAIMER}

Portions of this document may be illegible in electronic image products. Images are produced from the best available original document. 
Y/SUB/99-MVM64/5

\title{
Y-12 PLANT GROUNDWATER PROTECTION PROGRAM GROUNDWATER AND SURFACE WATER \\ SAMPLING AND ANALYSIS PLAN \\ FOR CALENDAR YEAR 2000
}

\author{
Prepared by \\ AJA TECHNICAL SERVICES, INC. \\ Under Subcontract 70Y-MVM64V \\ September 1999 \\ for the \\ Environmental Compliance Department \\ Environment, Safety, and Health Organization \\ Oak Ridge Y-12 Plant \\ Oak Ridge, Tennessee 37831
}

Managed by

LOCKHEED MARTIN ENERGY SYSTEMS, INC. for the U.S. DEPARTMENT OF ENERGY under contract No. DE-AC05-84OR21400 
TABLE OF CONTENTS

\section{Section}

List of Figures iii

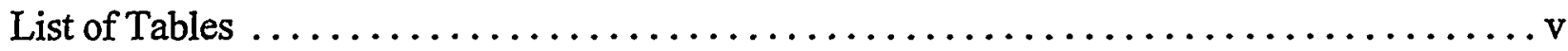

List of Acronyms and Abbreviations $\ldots \ldots \ldots \ldots \ldots \ldots \ldots \ldots \ldots \ldots \ldots \ldots \ldots \ldots \ldots$ vii

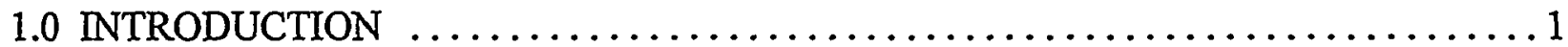

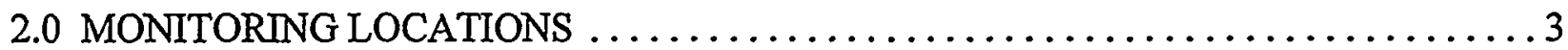

3.0 SAMPLE COLLECTION AND HANDLING $\ldots \ldots \ldots \ldots \ldots \ldots \ldots \ldots \ldots \ldots \ldots \ldots \ldots \ldots \ldots \ldots$

4.0 FIELD MEASUREMENTS AND ANALYTICAL PARAMETERS $\ldots \ldots \ldots \ldots \ldots \ldots 7$

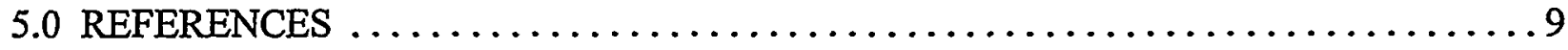

\section{APPENDICES:}

A Figures

B Tables 


\section{List of Figures}

Figure

1 Hydrogeologic regimes at the $\mathrm{Y}-12$ Plant $\ldots \ldots \ldots \ldots \ldots \ldots \ldots \ldots \ldots \ldots \ldots$

2 Sampling locations in the Bear Creek Hydrogeologic Regime, CY 2000 . . . . . A A-2

3 Sampling locations in the Chestnut Ridge Hydrogeologic Regime, CY $2000 \ldots$. . . A-3

4 Sampling locations in the Upper East Fork Poplar Creek

Hydrogeologic Regime, CY $2000 \ldots \ldots \ldots \ldots \ldots \ldots \ldots \ldots \ldots \ldots \ldots \ldots$

5 Surface water sampling locations north of Pine Ridge, CY $2000 \ldots \ldots \ldots \ldots$. A-5 


\section{List of Tables}

Table

Page

1 Sampling sequence, frequency, and analytical parameters for groundwater and surface water monitoring during CY $2000 \ldots \ldots \ldots \ldots \ldots \ldots \ldots$. 1

2 Field measurements and laboratory analytes for CY 2000 groundwater and surface water samples $\ldots \ldots \ldots \ldots \ldots \ldots \ldots \ldots \ldots \ldots \ldots \ldots \ldots \ldots \ldots \ldots \ldots$ 


\section{List of Acronyms and Abbreviations}

$\mathrm{ACO}$

Bear Creek Regime

Chestnut Ridge Regime

CY

DOE

East Fork Regime

GWPP

LMES

SWDF
Analytical Chemistry Organization

Bear Creek Hydrogeologic Regime (BC sample groups)

Chestnut Ridge Hydrogeologic Regime (CR sample groups)

Calendar Year

U.S. Department of Energy

Upper East Fork Poplar Creek Hydrogeologic Regime (EF sample groups) Groundwater Protection Program

Lockheed Martin Energy Systems, Inc.

Solid Waste Disposal Facility 


\subsection{INTRODUCTION}

This plan provides a description of the groundwater and surface water quality monitoring activities planned for calendar year (CY) 2000 at the U.S. Department of Energy (DOE) Y-12 Plant that will be managed by the Y-12 Plant Groundwater Protection Program (GWPP). Groundwater and surface water monitoring during CY 2000 will be performed in three hydrogeologic regimes at the Y-12 Plant: the Bear Creek Hydrogeologic Regime (Bear Creek Regime), the Upper East Fork Poplar Creek Hydrogeologic Regime (East Fork Regime), and the Chestnut Ridge Hydrogeologic Regime (Chestnut Ridge Regime). The Bear Creek and East Fork regimes are located in Bear Creek Valley, and the Chestnut Ridge Regime is located south of the Y-12 Plant (Figure 1).

Groundwater and surface water monitoring performed under the auspices of the Y-12 Plant GWPP during CY 2000 will comply with:

- Tennessee Department of Environment and Conservation regulations governing detection monitoring at nonhazardous Solid Waste Disposal Facilities (SWDF); and

- DOE Order 5400.1 surveillance monitoring and exit pathway/perimeter monitoring.

Some of the data collected for these monitoring drivers also will be used to meet monitoring requirements of the Integrated Water Quality Program, which is managed by Bechtel Jacobs Company LLC. Data from five wells that are monitored for SWDF purposes in the Chestnut Ridge Regime will be used to comply with requirements specified in the Resource Conservation and Recovery Act post closure permit regarding corrective action monitoring.

Modifications to the CY 2000 monitoring program may be necessary during implementation. Changes in regulatory or programmatic requirements may alter the analytes specified for selected monitoring wells, or wells could be added or removed from the planned monitoring network. All modifications to the monitoring program will be approved by the Y-12 Plant GWPP manager and documented as addenda to this sampling and analysis plan. 


\subsection{MONITORING LOCATIONS}

The Y-12 Plant GWPP monitoring network for CY 2000 includes 111 monitoring locations. Groundwater samples will be collected from a total of 79 monitoring wells, including 23 wells located in the Bear Creek Regime (Figure 2), 17 wells located in the Chestnut Ridge Regime (Figure 3), and 39 wells (one well has 10 monitoring locations) located in the East Fork Regime (Figure 4). Samples of groundwater discharging from 10 natural springs also will be collected, including four springs (SS-1, SS-4, SS-5, and SS-6) in the Bear Creek Regime (Figure 2) and six springs (SCR2.1SP, SCR2.2SP, SCR3.4SP, SCR4.3SP, SCR5.1SP, and SCR5.4SP) in the Chestnut Ridge Regime (Figure 3). Surface water samples will be collected from 13 sampling locations during CY 2000, including seven locations in the Bear Creek Regime, one location in the East Fork Regime, and five locations north of Pine Ridge. In the Bear Creek Regime, samples will be collected from Bear Creek at six sampling stations located from about 0.6 to 12 kilometers upstream of the confluence of Bear Creek and East Fork Poplar Creek (BCK-00.63 to BCK-11.97), and from one sampling station along a northern tributary (NT-01) to Bear Creek (Figure 2). In the East Fork Regime, samples will be collected from the Lake Reality Emergency Spillway (Figure 4). The locations north of Pine Ridge include samples collected from three tributaries (NPR07.0SW, NPR10.0SW, and NPR12.0SW) along the north slope of Pine Ridge near the Scarboro Community and two tributaries (GHK2.51ESW and GHK2.51WSW) near Country Club Estates (Figure 5). 


\subsection{SAMPLE COLLECTION AND HANDLING}

Monitoring wells, springs, and surface water stations are subdivided into sample groups based on hydrogeologic regimes. These sample groups, located in the Bear Creek (BC), Chestnut Ridge (CR), and East Fork (EF) hydrogeologic regimes, will be sampled in the sequence shown on Table 1. The sampling sequence is generally from least contaminated to most contaminated location within each sampling group. Groundwater samples will be collected using dedicated sampling equipment (Well Wizard ${ }^{\mathrm{TM}}$ bladder pumps) unless a well is equipped with a Westbay ${ }^{\mathrm{TM}}$ multiport sampling system or is specified for conventional method sample collection (Table 1).

Personnel from the Y-12 Plant Analytical Chemistry Organization (ACO) will be responsible for collection, transportation, and chain-of-custody control of the groundwater and surface water samples. Sampling will be performed in accordance with the most recent version of Y-12 Plant System Operating Procedures approved by the Y-12 Plant GWPP Manager for obtaining groundwater samples (Lockheed Martin Energy Systems, Inc. [LMES] 1996a, 1996b, 1997), surface water samples (LMES 1999a), and field measurments (LMES 1996c, 1999b, and 1999c).

During CY 2000, most groundwater samples will be obtained using the low-flow minimal drawdown purging and sampling method (low-flow method); however, the conventional sampling method (three well-volume purging) will be used where specified (Table 1), and the sampling method for wells equipped with a Westbay ${ }^{\mathrm{TM}}$ multiport sampling system (Westbay method) will be used where applicable. Groundwater samples collected using the low-flow method will be obtained using dedicated bladder pumps (Well Wizard ${ }^{\mathrm{TM}}$ ). In accordance with the procedure for the low-flow method (LMES 1997), groundwater samples will be collected from the well immediately following the stabilization (minimal variation over four consecutive readings) of field measurements $(\mathrm{pH}$, conductivity, temperature, oxidation-reduction potential, and dissolved oxygen) in the groundwater purged from the well at a low flow rate $(<300$ milliliters per minute) to ensure minimal drawdown of the water level in the well $(<0.1$ foot per quarter-hour). Using this sampling method, representative groundwater samples are obtained with no influence from the stagnant water in the well casing. This method differs from the conventional sampling method, which involves pumping at least three well volumes at higher purge rates ( 1 to 2 gallons per minute) before collecting samples from the well.

Groundwater samples from five monitoring wells will be collected using the conventional sampling method during CY 2000 (Table 1). These locations include three wells in the Bear Creek Regime (GW-627, GW-706, and GW-725) and two wells in the East Fork Regime (GW-763 and GW-791). The conventional method samples will be obtained with portable gas-piston pumps (Bennet Pump ${ }^{\mathrm{TM}}$ ) a few days after collecting the low-flow method samples from these wells. The paired results for these locations will be compared to evaluate the differences in groundwater quality data obtained by each sampling method.

Groundwater sampling using a Westbay ${ }^{\mathrm{TM}}$ multiport sampling system at well GW-722 will be performed in accordance with the most recent and approved operating procedures (LMES 1996a and 1996b). The groundwater samples from each sampling port will be collected in a 250-milliliter nonvented stainless steel sample collection bottle filled at the designated depth in the well by opening the sampling port valve. Once filled, the bottle is raised to the surface and the sample is transferred to laboratory sample bottles. Normally, a sample collection bottle will be filled about 
seven times at each port to obtain enough groundwater to fill all of the laboratory sample bottles. The first sample bottle is used as a "formation rinse" to obtain field measurements and condition the sample bottle for each particular zone.

Because preliminary results have shown that the low-flow sampling method provides less turbid samples than the conventional sampling method, filtered samples will be collected only from specified monitoring locations (Table 1). These locations include all of the sample groups in the Chestnut Ridge Regime, Westbay well GW-722 in the East Fork Regime, and the surface water locations north of Pine Ridge. These samples will be filtered in the field using a 0.45 -micron filter. All samples will be collected in appropriate containers, labeled, logged, placed in ice-filled coolers, and transported to the appropriate ACO laboratory in accordance with chain-of-custody control requirements.

Samples will be collected semiannually from all of the monitoring wells, springs, and surface water stations in each regime during CY 2000. As summarized below, the number of samples to be collected during each quarter will range from 48 to 63 , for an annual total of 222 samples.

\begin{tabular}{|c|c|c|}
\hline \multirow{2}{*}{ HYDROGEOLOGIC } & \multicolumn{2}{|c|}{ NUMBER OF SAMPLES PER QUARTER OF CY 2000 } \\
\cline { 2 - 3 } REGIME/AREA & 1st and 3rd & 2nd and 4th \\
\hline Bear Creek Regime & 37 & 0 \\
Chestnut Ridge Regime & 16 & 7 \\
East Fork Regime & 10 & 41 \\
North of Pine Ridge & 5 & 0 \\
\hline Total: & $\mathbf{6 3}$ & $\mathbf{4 8}$ \\
\hline
\end{tabular}

In addition to the groundwater and surface water samples, field blanks and equipment rinsate samples will be collected at the frequencies and analyzed for the parameters specified on Table 1. Field blank samples will be collected from at least $10 \%$ of the sample groups. A field blank will be collected during each quarter of CY 2000: at BC-2 during the first and third quarters and at EF-2 during the second and fourth quarters. Equipment rinsate samples will be collected from well GW-722 (EF-WB) and from the wells scheduled for conventional sampling (Table 1). The rinsate sample will be obtained in the field immediately after field-cleaning the sampling equipment after collecting samples from the last sampling port (GW-722-17) or after the last well sampled with a particular pump.

Trip blank samples, field duplicate samples, and laboratory quality assurance samples will be prepared and analyzed as specified in the ACO Laboratory Quality Assurance Project Plan (Martin Marietta Energy Systems, Inc. 1991) using applicable analytical procedures. The location (building and room number) where the trip blank samples are prepared will be recorded on the field data sheets. Trip blank samples will be prepared for each cooler used to transport samples for volatile organic analyses. Duplicate samples will be collected from at least $10 \%$ of the sampling locations. A total of 28 field duplicate samples will be collected during CY 2000, including six in the Bear Creek Regime, 10 in the Chestnut Ridge Regime, 10 in the East Fork Regime, and two from offsite surface water stations (Table 1). 


\subsection{FIELD MEASUREMENTS AND ANALYTICAL PARAMETERS}

Field personnel will measure the depth to water before purging and sampling groundwater in each monitoring well. Sampling personnel also will record field measurements of $\mathrm{pH}$, temperature, conductivity, dissolved oxygen, and oxidation-reduction potential before collecting samples at each monitoring location (Table 2).

The monitoring drivers for CY 2000 require an extensive list of analytes (Table 2). For this Sampling and Analysis Plan, specific analytes are grouped by analytical method or by type (e.g., metals) and referenced as analytical parameters. In addition to field measurements, all groundwater and surface water samples will be analyzed for the following suite of parameters (identified as the Standard Administrative Parameter Group):

- miscellaneous laboratory analytes - $\mathrm{pH}$, conductivity, turbidity, total suspended solids, and total dissolved solids;

- major anions;

- $\quad$ trace metals (includes major cations);

- a comprehensive suite of organic compounds; and

- gross alpha and gross beta activity.

Unfiltered groundwater and surface water samples will be analyzed for all of the standard laboratory analytes; filtered samples will be analyzed only for the trace metals.

The Y-12 Plant National Pollution Elimination System Program requested results for several radionuclides in addition to the analytes included in the Standard Administrative Parameter Group for surface water samples from BCK-11.97 in BC-3 (Table 1). Groundwater samples from six monitoring wells in the East Fork regime also will be analyzed for specified radionuclides. 



\subsection{REFERENCES}

Martin Marietta Energy Systems, Inc. 1991. Laboratory Quality Assurance Project Plan for the Sampling and Analysis of Groundwater Wells at the Y-12 Plant Site on the Oak Ridge Reservation. Prepared by Analytical Chemistry Department Technical Division, QAP: 04-90-0014.

Lockheed Martin Energy Systems, Inc. 1996a. Groundwater Sampling of Westbay ${ }^{\mathrm{TM}}$ Monitoring System Instrumented Wells. Y-12 Plant Command Media prepared by the Health, Safety, Environment, and Accountability Organization (Y50-66-EM-350).

Lockheed Martin Energy Systems, Inc. 1996b. Pressure Profiling of Wells Equipped with Westbay ${ }^{\mathrm{TM}}$ Monitoring System Instrumentation. Y-12 Plant Command Media prepared by the Health, Safety, Environment, and Accountability Organization (Y50-66-EM-352).

Lockheed Martin Energy Systems, Inc. 1996c. Redox Meter Calibration and Operation. Prepared by the Analytical Services Organization (SESD-TP-8201, Rev. 2).

Lockheed Martin Energy Systems, Inc. 1997. Groundwater Sampling. Prepared by the Analytical Services Organization (SESD-TP-8204, Rev. 3).

Lockheed Martin Energy Systems, Inc. 1999a. Liquid Grab Sampling. Y-12 Plant Command Media prepared by the Health, Safety, Environment, and Accountability Organization (Y5071-005).

Lockheed Martin Energy Systems, Inc. 1999b. Field Measurements of Physical and Chemical Characteristics. Y-12 Plant Command Media prepared by the Health, Safety, Environment, and Accountability Organization (Y50-71-001).

Lockheed Martin Energy Systems, Inc. 1999c. Measurement of Static Water Level Elevation. Y-12 Plant Command Media prepared by the Health, Safety, Environment, and Accountability Organization (Y50-71-015).

U.S. Environmental Protection Agency. 1983. Methods for Chemical Analysis of Water and Wastes.

U.S. Environmental Protection Agency. 1996. Test Methods for Evaluating Solid Waste Physical/Chemical Methods. 
APPENDIX A

\section{FIGURES}




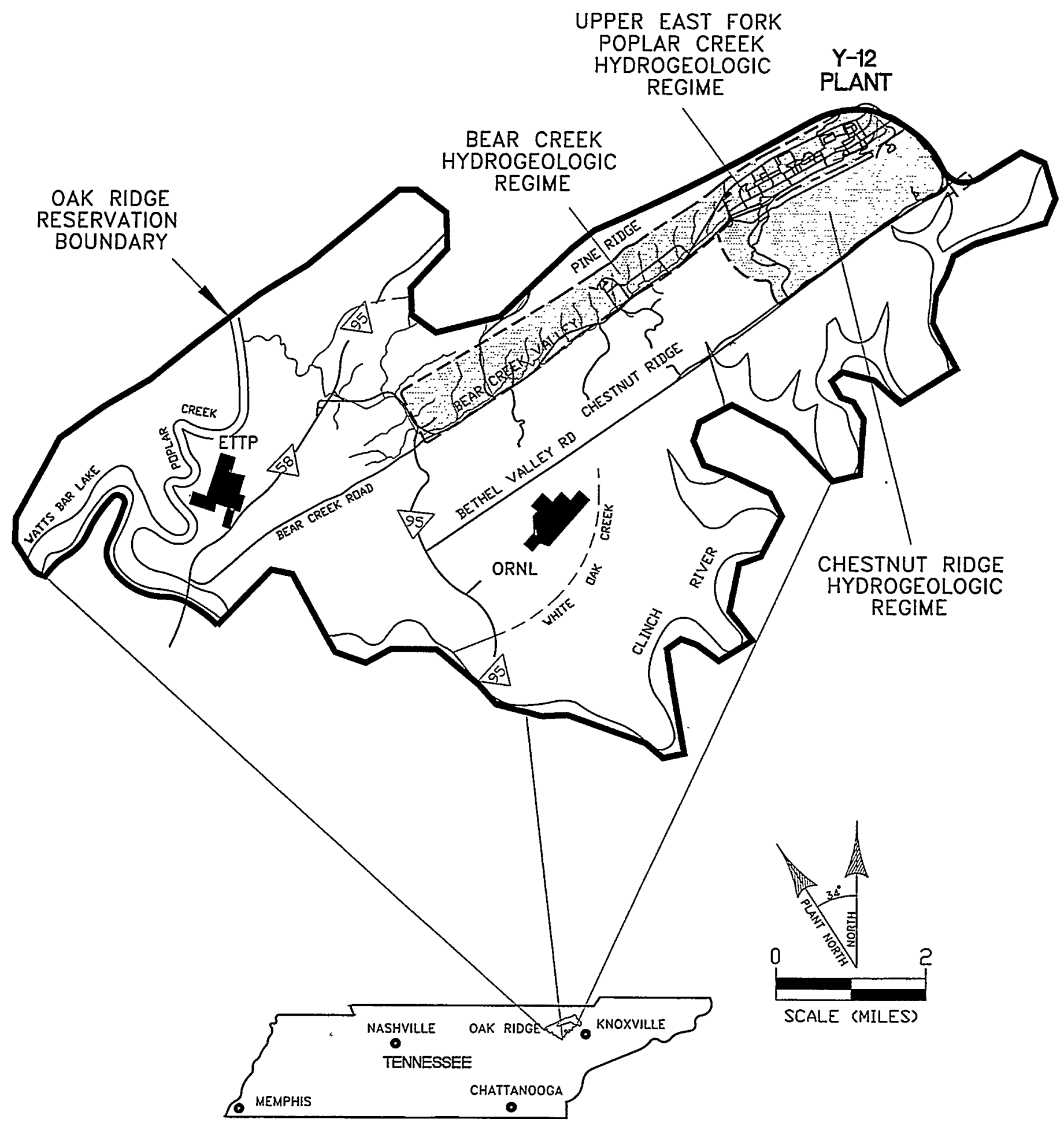




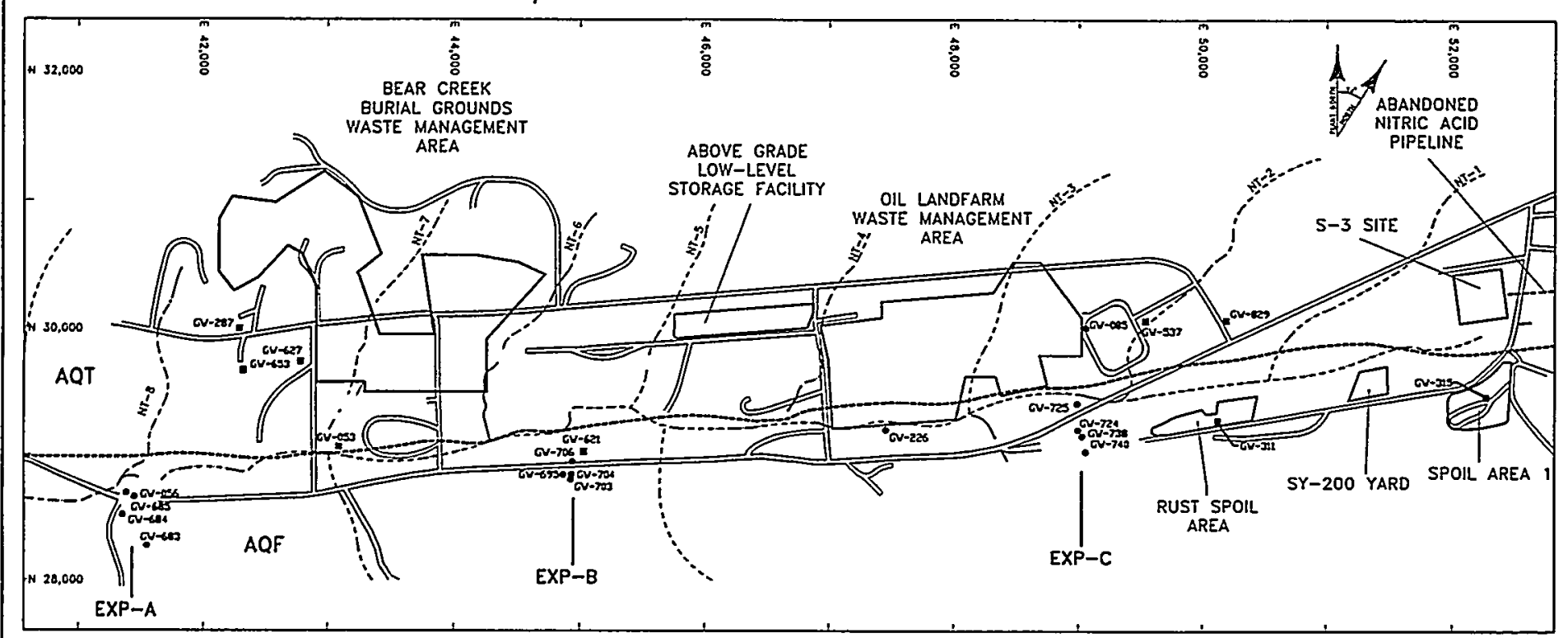

MONITORING WELLS

O 1650

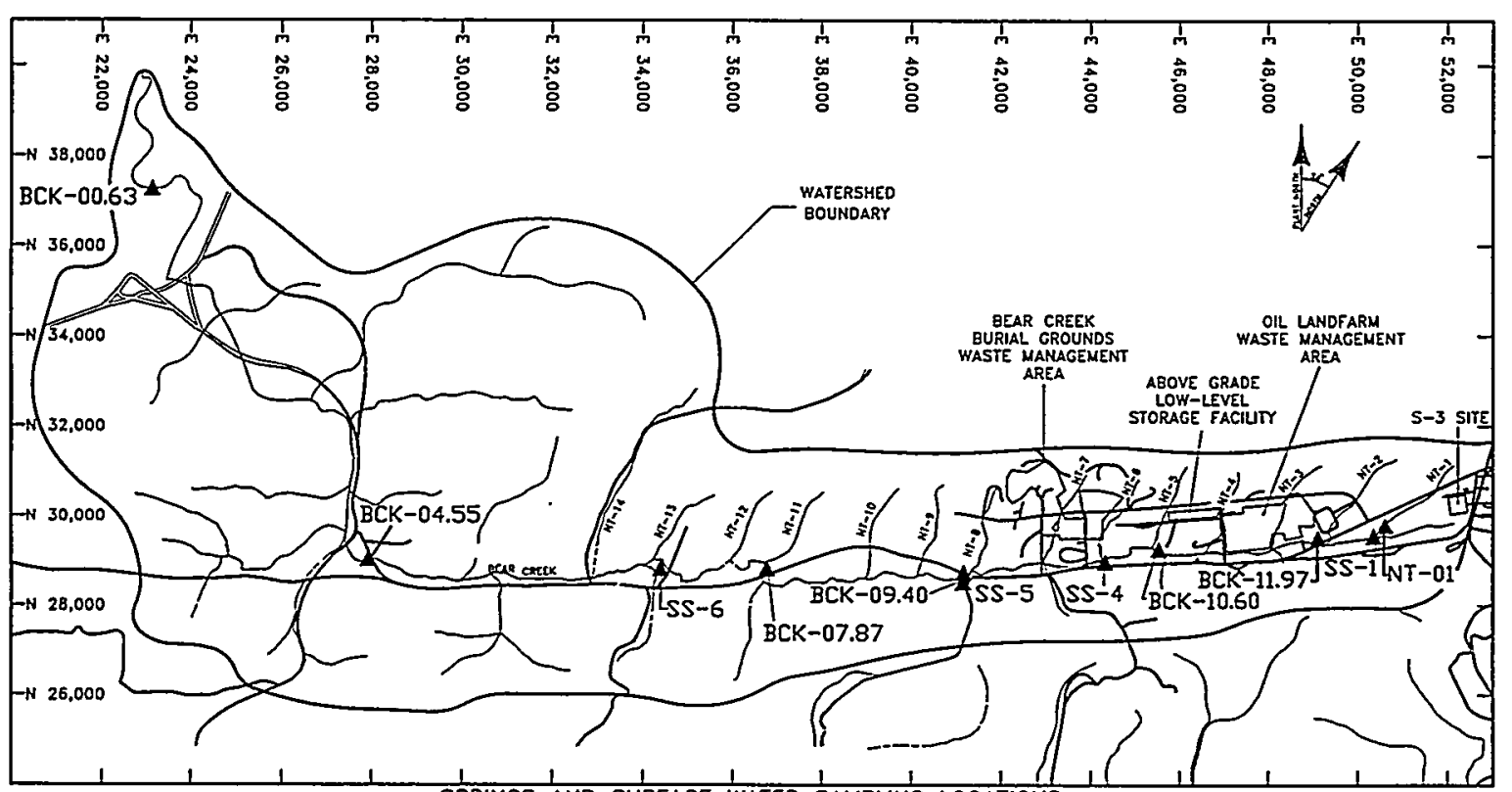

$\frac{1}{1} \frac{1}{1} \frac{1}{1} \frac{1}{1} \frac{1}{1}$

$$
{ }_{\text {SCALE (I) }}^{4050}
$$

EXPLANATION

- Woler Toble Monitoring Well
- Bedrock Monitoring Well
- Spring or Surfoce Woler Sampling Stotion
EXP-C - Exit Pothwoy, - Moynordville Limestone Pieket
AQT-S - North Tributary
AQT - Aquiterd
AQTuifer



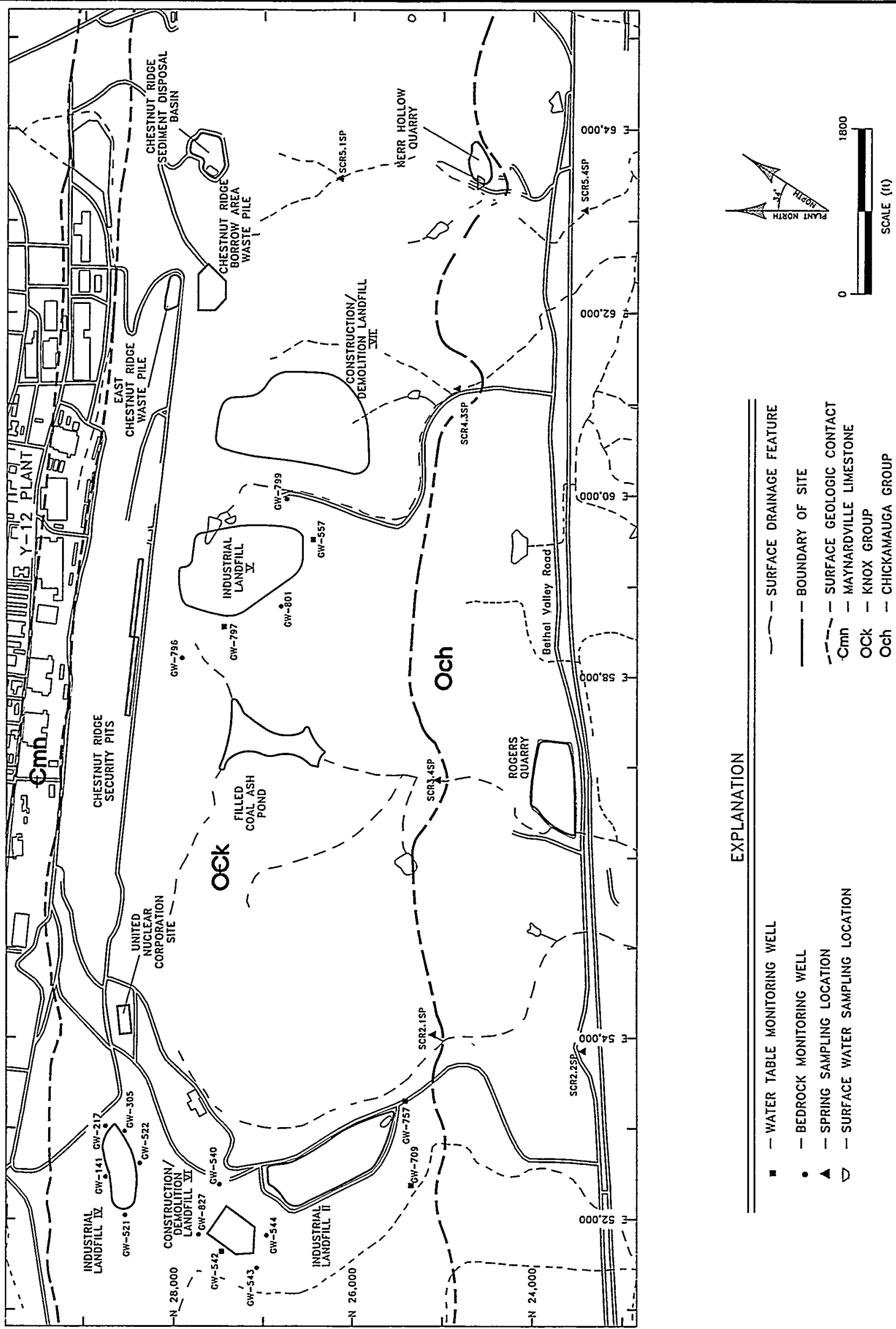

$z$
을
$\frac{z}{z}$
$\frac{5}{a}$
$\frac{a}{x}$
$w$

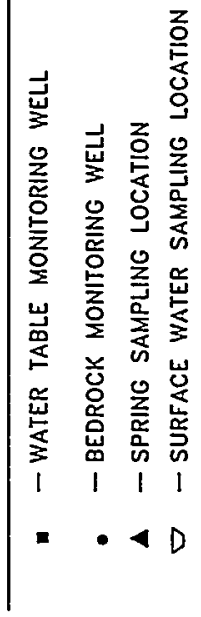




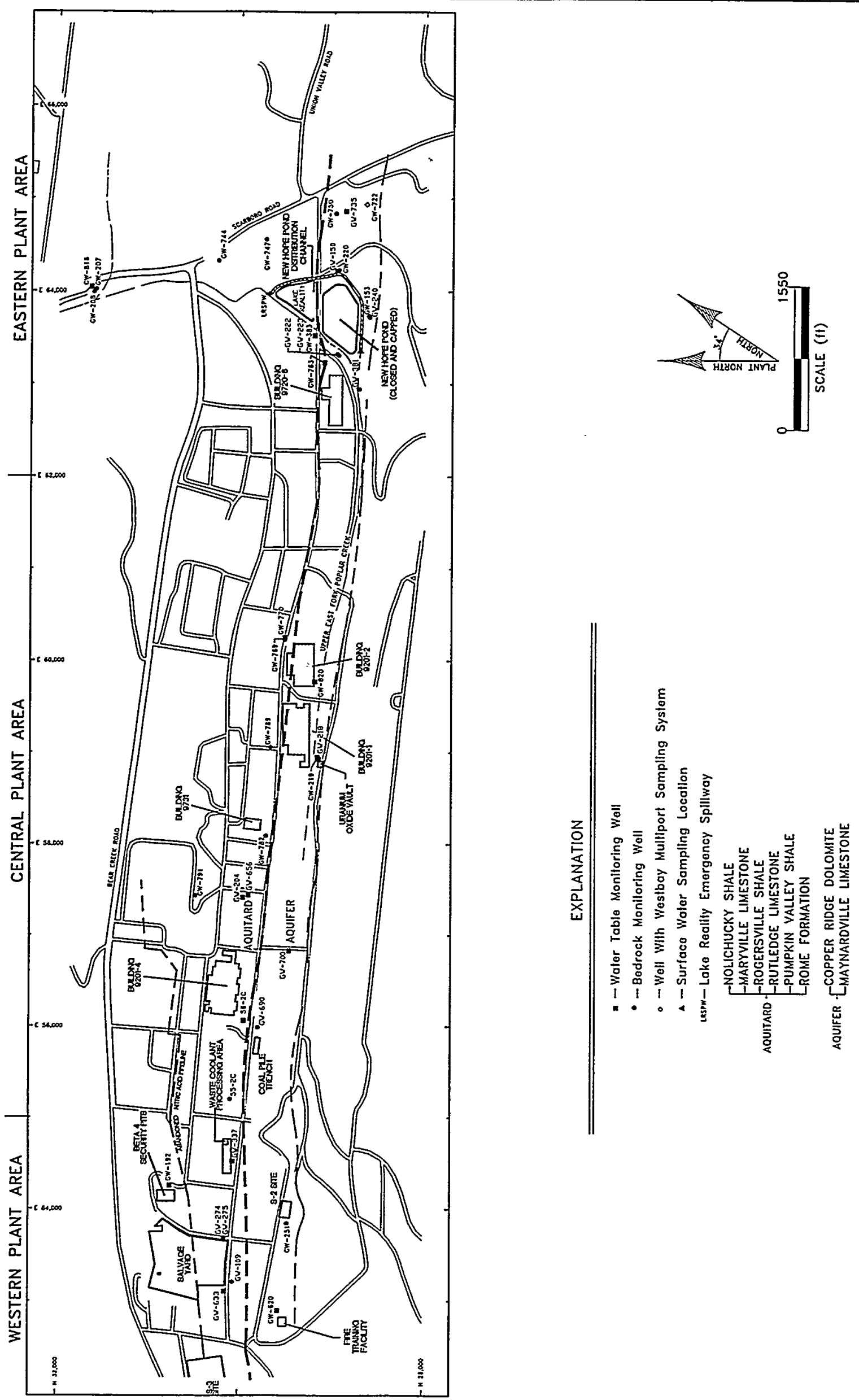




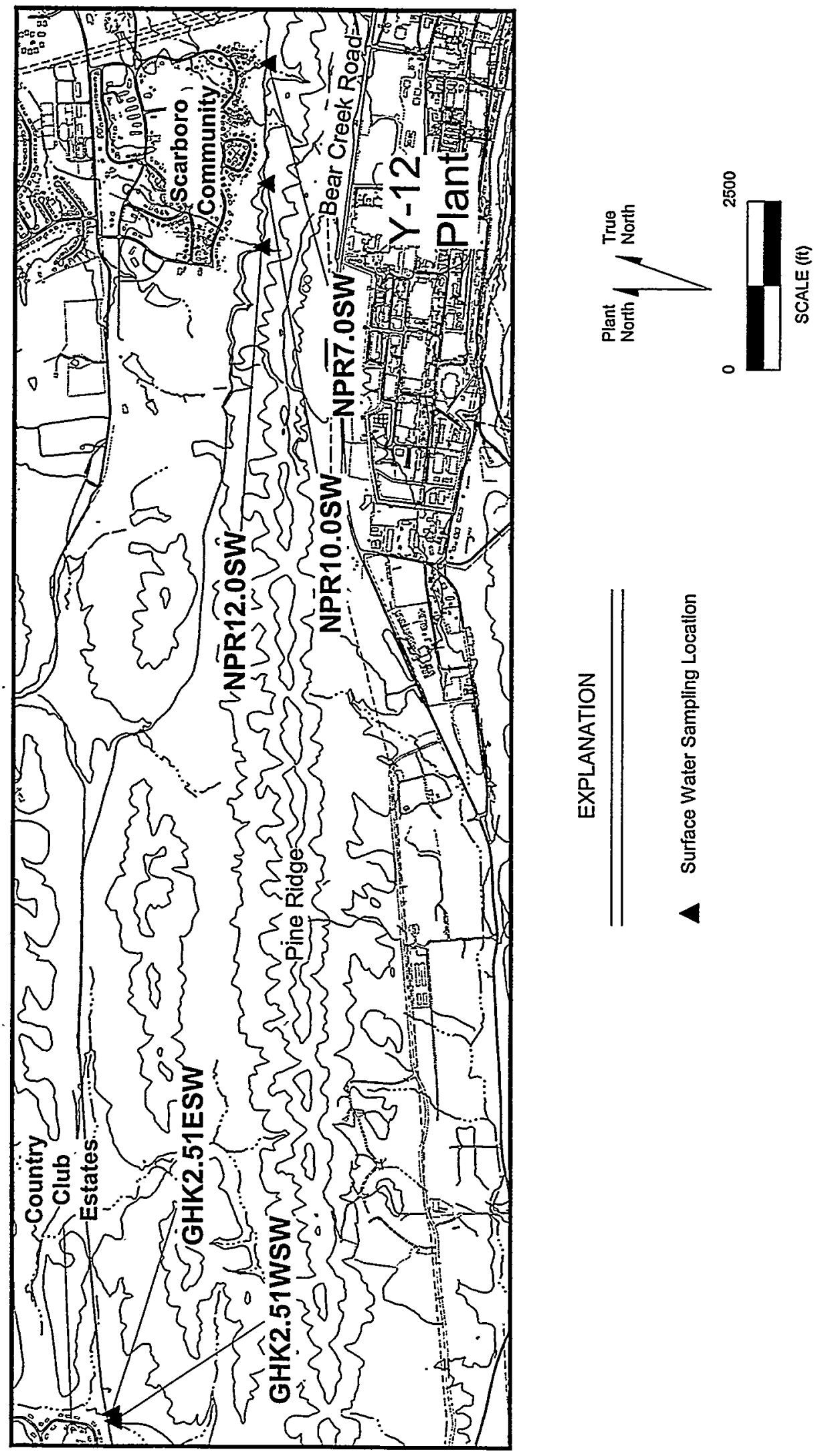

Fig. 5. Surface water sampling locations north of Pine Ridge, CY 2000. 
APPENDIX B

TABLES 
Table 1. Sampling sequence, frequency, and analytical parameters for groundwater and surface water monitoring during CY 2000

\begin{tabular}{|c|c|c|c|c|c|c|}
\hline \%ै Sample & Location? & 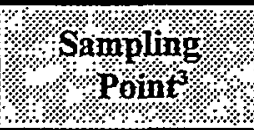 & benplicater & Contains & Monitoring & (1) \\
\hline \multicolumn{7}{|c|}{ Bear Creek Hydrogeologic Regime } \\
\hline \multirow{13}{*}{$\begin{array}{l}\mathrm{BC}-1 \\
(\mathrm{Q} 1, \mathrm{Q} 3)\end{array}$} & EXP-A & GW-056 & Q1 & & SMP & STD \\
\hline & EXP-A & GW-685 & & - & SMP & STD \\
\hline & EXP-A & GW-684 & & $\mathrm{Y}$ & SMP & STD \\
\hline & EXP-A & GW-683 & & $\mathrm{Y}$ & SMP & STD \\
\hline & EXP-B & GW-621 & & & SMP & STD \\
\hline & EXP-B & GW-695 & & $\mathrm{Y}$ & SMP & STD \\
\hline & EXP-B & GW-703 & & $\mathrm{Y}$ & SMP & STD \\
\hline & EXP-B & GW-704 & & $\mathrm{Y}$ & SMP & STD \\
\hline & EXP-B & GW-706 & $\mathrm{C}$ & $\mathrm{Y}$ & SMP & STD \\
\hline & EXP-C & GW-740 & & $\mathrm{Y}$ & SMP & STD \\
\hline & EXP-C & GW-738 & & $\mathrm{Y}$ & SMP & STD \\
\hline & EXP-C & GW-724 & Q3 & $Y$ & SMP & STD \\
\hline & EXP-C & GW-725 & $\mathrm{C}$ & $\mathrm{Y}$ & SMP & STD \\
\hline \multirow{11}{*}{$\begin{array}{l}\mathrm{BC}-2 \\
(\mathrm{Q} 1, \mathrm{Q} 3)\end{array}$} & $\mathrm{BG}$ & GW-287 & Q1 & $Y$ & SMP & STD \\
\hline & $\mathrm{BG}$ & GW-653 & & $Y$ & SMP & STD \\
\hline & $\mathrm{BG}$ & GW-053 & & $Y$ & SMP & STD \\
\hline & $\mathrm{BG}$ & GW-627 & C & $\mathrm{Y}$ & SMP & STD \\
\hline & SPI & GW-315 & & $\mathrm{Y}$ & SMP & STD \\
\hline & RS & GW-311 & Q3 & $Y$ & SMP & STD \\
\hline & OLF & GW-829 & & $\mathrm{Y}$ & SMP & STD \\
\hline & OLF & GW-085 & & $\mathrm{Y}$ & SMP & STD \\
\hline & OLF & GW-537 & & $\mathrm{Y}$ & SMP & STD \\
\hline & OLF & GW-226 & & $Y$ & SMP & STD \\
\hline & \multicolumn{5}{|c|}{ FIELD BLANK } & $\operatorname{VOC}(1)$ \\
\hline
\end{tabular}


Table 1 (continued)

\begin{tabular}{|c|c|c|c|c|c|c|}
\hline . Sample Group $^{1}$ ? & 16oafiont & samping & opisticate & Qontain & Monitoring & 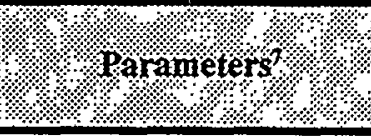 \\
\hline \multirow{11}{*}{$\begin{array}{l}\mathrm{BC}-3 \\
(\mathrm{Q} 1, \mathrm{Q} 3)\end{array}$} & EXP-SW & BCK-00.63 & & & EXP & STD \\
\hline & EXP-SW & BCK-04.55 & & & EXP & STD \\
\hline & EXP-SW & SS-6 & Q1 & & EXP & STD \\
\hline & EXP-SW & BCK-07.87 & & & EXP & STD \\
\hline & EXP-SW & SS-5 & & & EXP & STD \\
\hline & EXP-SW & BCK-09.40 & & & EXP & STD \\
\hline & EXP-SW & SS-4 & & & EXP & STD \\
\hline & EXP-SW & BCK-10.60 & Q3 & & EXP & STD \\
\hline & EXP-SW & BCK-11.97 & & & EXP & $\operatorname{STD}, \operatorname{RAD}(2,3,4,5,8,13)$ \\
\hline & EXP-SW & SS-1 & & & EXP & STD \\
\hline & EXP-SW & NT-01 & & & EXP & STD \\
\hline \multicolumn{7}{|c|}{ Chestnut Ridge Hydrogeologic Regime } \\
\hline \multirow{5}{*}{$\begin{array}{l}\text { CR-1 } \\
(Q 1, Q 3)\end{array}$} & LIV & GW-217 & & & SDM & STD/F \\
\hline & LIV & GW-141 & Q1 & & SDM & STD/F \\
\hline & LIV & GW-521 & & & SDM/CMP & STD/F \\
\hline & LIV & GW-522 & Q3 & & SDM & $\mathrm{STD} / \mathrm{F}$ \\
\hline & LIV & GW-305 & & $\mathbf{Y}$ & SDM & STD/F \\
\hline \multirow{6}{*}{$\begin{array}{l}\text { CR-2 } \\
(\mathrm{Q} 1, \mathrm{Q} 3)\end{array}$} & LV & GW-557 & & & SDM/CMP & STD/F \\
\hline & LV & GW-799 & & & SDM/CMP & $\mathrm{STD} / \mathrm{F}$ \\
\hline & $\mathrm{LV}$ & GW-797 & Q3 & & SDM & STD/F \\
\hline & LV & GW-801 & & & SDM/CMP & $\mathrm{STD} / \mathrm{F}$ \\
\hline & LV & GW-796 & & & SDM/CMP & $\mathrm{STD} / \mathrm{F}$ \\
\hline & LV & SCR4.3SP & Q1 & & SDM/EXP & STD/F \\
\hline \multirow{5}{*}{$\begin{array}{l}\text { CR-3 } \\
(\mathrm{Q} 1, \mathrm{Q} 3)\end{array}$} & EXP-SW & SCR2.1SP & & & EXP & STD/F \\
\hline & EXP-SW & SCR2.2SP & & & EXP & STD/F \\
\hline & EXP-SW & SCR3.4SP & & & EXP & $\mathrm{STD} / \mathrm{F}$ \\
\hline & EXP-SW & SCR5.1SP & Q1 & & EXP & STD/F \\
\hline & EXP-SW & SCR5.4SP & Q3 & & EXP & $\mathrm{STD} / \mathrm{F}$ \\
\hline
\end{tabular}


Table 1 (continued)

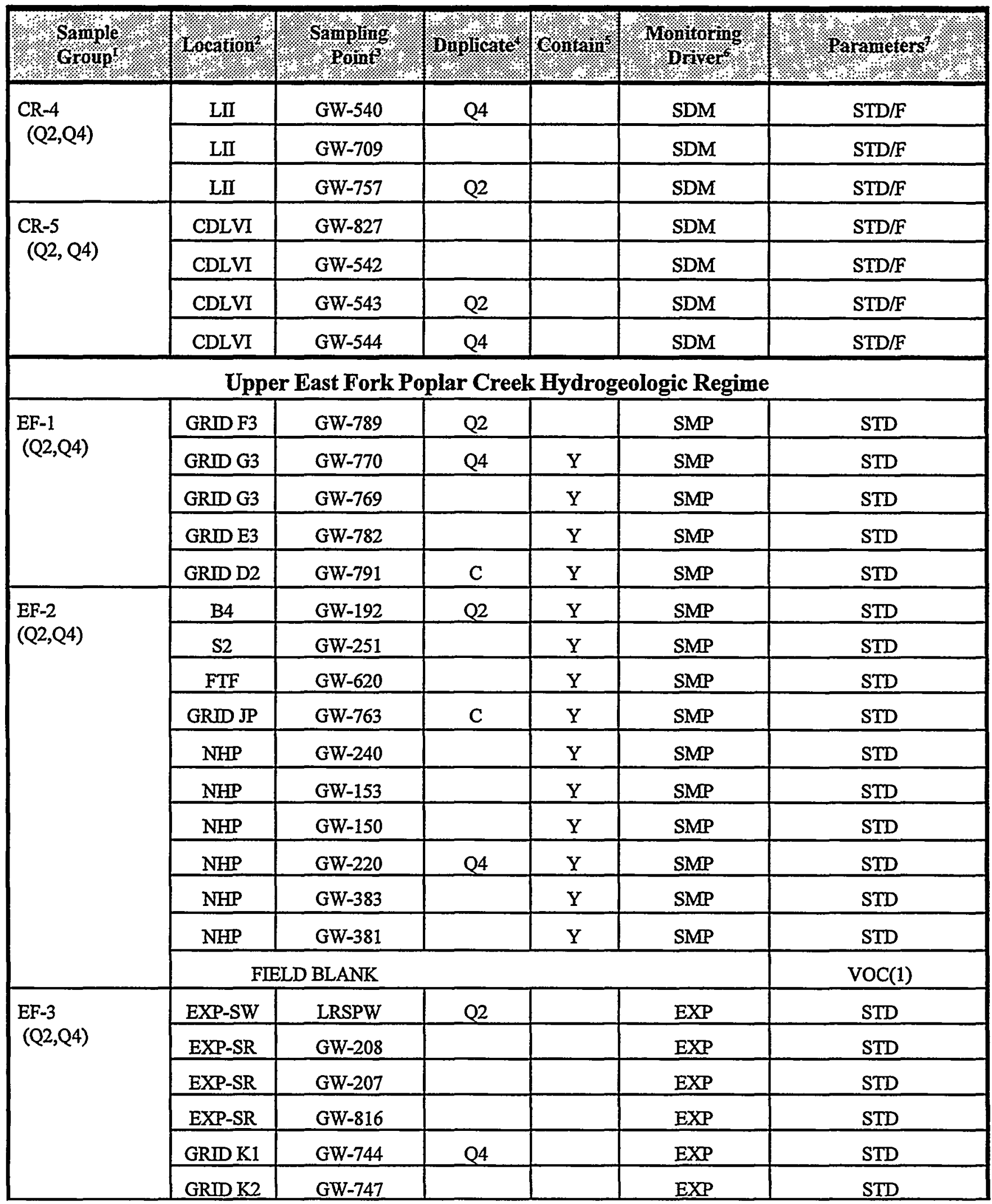


Table 1 (confinued)

\begin{tabular}{|c|c|c|c|c|c|c|}
\hline . & 4.ocationt: & Sampling & pinplicarer. & Gontanin: & Monitoring & \% \\
\hline \multirow{2}{*}{$\begin{array}{l}\text { EF-3 (continued) } \\
(\mathrm{Q} 2, \mathrm{Q} 4)\end{array}$} & EXP-J & GW-750 & & & EXP & STD \\
\hline & EXP-J & GW-735 & & & EXP & STD \\
\hline \multirow{16}{*}{$\begin{array}{l}\mathrm{EF}-4 \\
(\mathrm{Q} 2, \mathrm{Q} 4)\end{array}$} & GRID B3 & $55-2 C$ & & $\mathrm{Y}$ & SMP & STD \\
\hline & GRID C3 & $56-2 C$ & & $\mathrm{Y}$ & SMP & STD \\
\hline & SY & GW-274 & & $\mathrm{Y}$ & SMP & STD, RAD(12) \\
\hline & SY & GW-275 & & $Y$ & SMP & STD, RAD(12) \\
\hline & $\mathrm{RG}$ & GW-633 & & $\mathrm{Y}$ & SMP & STD, RAD(12) \\
\hline & S3 & GW-109 & & $\mathrm{Y}$ & SMP & STD, RAD(12) \\
\hline & WCPA & GW-337 & & $Y$ & SMP & STD \\
\hline & T0134 & GW-204 & & $Y$ & SMP & STD \\
\hline & T0134 & GW-656 & & $\mathrm{Y}$ & SMP & STD \\
\hline & UOV & $G W-218$ & & $\mathrm{Y}$ & SMP & STD, RAD(3) \\
\hline & UOV & GW-219 & Q2 & $\mathrm{Y}$ & SMP & STD, RAD(3) \\
\hline & $\mathrm{CPT}$ & GW-690 & & $\mathrm{Y}$ & SMP & STD, RAD(12) \\
\hline & B8110 & GW-700 & & $\mathrm{Y}$ & SMP & STD \\
\hline & B9201-2 & GW-820 & Q4 & $\mathrm{Y}$ & SMP & STD \\
\hline & NHP & GW-222 & & $\mathrm{Y}$ & SMP & STD \\
\hline & NHP & GW-223 & & $\mathrm{Y}$ & SMP & STD \\
\hline \multirow{11}{*}{$\begin{array}{l}\text { EF-WB } \\
(\mathrm{Q} 1, \mathrm{Q} 3)\end{array}$} & EXP-J & GW-722-06 & & & EXP & STD/F \\
\hline & EXP-J & GW-722-30 & & & EXP & STD/F \\
\hline & EXP-J & GW-722-26 & Q1 & & EXP & STD/F \\
\hline & EXP-J & GW-722-32 & & & EXP & STD/F \\
\hline & EXP-J & GW-722-33 & & & EXP & STD/F \\
\hline & EXP-J & GW-722-10 & & & EXP & STD/F \\
\hline & EXP-J & GW-722-22 & $\mathrm{Q} 3$ & & EXP & $\mathrm{STD} / \mathrm{F}$ \\
\hline & EXP-J & GW-722-20 & & & EXP & STD/F \\
\hline & EXP-J & GW-722-14 & & & EXP & STD/F \\
\hline & EXP-J & GW-722-17 & & & EXP & STD/F \\
\hline & \multicolumn{5}{|c|}{ RINSATE SAMPLE } & STD \\
\hline
\end{tabular}


Table 1 (continued)

\begin{tabular}{|c|c|c|c|c|c|c|}
\hline \%. Samplè & $10 \mathrm{cation}^{2}$ ? & Samping: & 10inglicate & Confan? & Monitoring & 4 paraneters? \\
\hline \multicolumn{7}{|c|}{ North of Pine Ridge } \\
\hline \multirow{5}{*}{$\begin{array}{l}\text { PR-1 } \\
(\mathrm{Q} 2, \mathrm{Q} 4)\end{array}$} & $\mathrm{SCA}$ & NPR07.0SW & & & SMP & $\mathrm{STD} / \mathrm{F}$ \\
\hline & SCA & NPR10.0SW & & & SMP & $\mathrm{STD} / \mathrm{F}$ \\
\hline & $\mathrm{SCA}$ & NPR12.0SW & & Q3 & SMP & STD/F \\
\hline & $\mathrm{CCE}$ & GHK2.51ESW & & & SMP & $\mathrm{STD} / \mathrm{F}$ \\
\hline & CCE & GHK2.51WSW & & Q1 & SMP & STD/F \\
\hline
\end{tabular}

\section{Notes:}

1 Samples will be collected during the calendar year quarter as specified (e.g., Q1). Surface water and spring samples in BC-3 will be collected on or about the same day as groundwater samples will be collected from wells GW-683 and GW-684 in BC-1. Spring samples in CR-3 will be collected about the same time as spring SCR4.3SP in CR-2.

Bear Creek Regime

BG - Bear Creek Burial Grounds Waste Management Area

EXP - Exit Pathway Monitoring Location: Maynardville Limestone Picket (-A, -B, -C) Spring or Surface Water Location (-SW)

OLF - Oil Landfarm Waste Management Area

RS - Rust Spoil Area

SPI - Spoil Area I

\section{Chestnut Ridge Regime}

CDLVI - Construction/Demolition Landfill VI

EXP-SW - Exit Pathway Monitoring Location (spring)

LII - Industrial Landfill II

LIV - Industrial Landfill IV

LV - Industrial Landfill V 


\section{Table 1 (continued)}

Notes: (continued)

East Fork Regime

B4 - Beta-4 Security Pits

B8110 - Building 81-10

B9201-2 - Building 9201-2

EXP-J - Maynardville Limestone Exit Pathway Picket J

EXP-SR - Exit pathway well in the gap through Pine Ridge along Scarboro Road (-SR)

EXP-SW - Surface water station (-SW)

FTF - Fire Training Facility

GRID - Comprehensive Groundwater Monitoring Plan Grid Location

NHP - New Hope Pond

RG - Rust Garage Area

UOV - Uranium Oxide Vault

S2 - S-2 Site

S3 - S-3 Site

SY - Y-12 Plant Salvage Yard

T0134 - Underground Tank T0134-U

WCPA - Waste Coolant Processing Area

North of Pine Ridge

SCA - Scarboro Community

CCE - Country Club Estates

3 BCK - Bear Creek Kilometer (Surface Water Sampling Station)

GW - Groundwater Monitoring Well

GHK - Gum Hollow Kilometer (Surface Water Sampling Station)

LRSPW - Lake Reality Spillway (Surface Water Sampling Station)

NPR - North Pine Ridge (Surface Water Sampling Station)

NT - North Tributary to Bear Creek

SCR - South Chestnut Ridge (Spring Sampling Station)

SS - Spring Sampling Location: South Side of Bear Creek

$4 \quad \mathrm{Q}$ - Field duplicate samples will be collected at these locations during the quarter specified.

C - For comparison of sampling method results, additional samples will be collected using the conventional sampling method (three well-volume purging) within a few days after the low-flow sampling event.

$5 \quad \mathrm{Y}-$ All purged groundwater will be contained at these locations.

6 CMP - RCRA Post-Closure Corrective Action Monitoring

EXP - DOE Order 5400.1A Exit Pathway/Perimeter Monitoring

SDM - SWDF Detection Monitoring

SMP - DOE Order 5400.1A Surveillance Monitoring 


\section{Table 1 (continued)}

\section{Notes: (continued)}

7 Table 2 provides a comprehensive list of analytes and analytical methods grouped by parameter.

/F - Includes filtered sample for dissolved metal concentrations.

STD - Standard administrative parameter group. See the following list of parameters that apply to CY 2000 samples.

Standard Administrative Parameter Group:

FLD - Field measurements

CHEM - Miscellaneous laboratory analytes (e.g., $\mathrm{pH}$ ) and anions

MET(1) - Metals

VOC(1) - Volatile organic compounds

$\mathrm{RAD}(1)$ - Gross alpha and gross beta

\section{Additional Radionuclides:}

$\mathrm{RAD}(2)$ - Strontium-89/90, technetium-99, and tritium

$\mathrm{RAD}(3)$ - Uranium-234, -235 , and -238

$\mathrm{RAD}(4)$ - Americium-241, iodine-129, neptunium-237, plutonium-238 and -239/240

$\mathrm{RAD}(5)$ - Radium-223/224/226

$\mathrm{RAD}(8)$ - Thorium-228, $-230,-232$, and -234

$\mathrm{RAD}(12)$ - Technetium-99

$\mathrm{RAD}(13)$ - Total uranium and weight percent U-235 
Table 2. Field measurements and laboratory analytes for CY 2000 groundwater and surface water samples

\begin{tabular}{|c|c|c|c|}
\hline 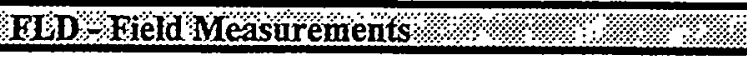 & Afialytical hnethod! & Detectionarimit? & Units \\
\hline Depth to Water & Y50-71-015 & NA & $\mathrm{ft}$ \\
\hline Water Temperature & Y50-71-001 & $\mathrm{NA}$ & centigrade \\
\hline $\mathrm{pH}$ & Y50-71-001 & $\mathrm{NA}$ & pH units \\
\hline Conductivity & Y50-71-001 & $\mathrm{NA}$ & $\mu \mathrm{mho} / \mathrm{cm}$ \\
\hline Dissolved Oxygen & Y50-71-001 & NA & ppm \\
\hline Oxidation-Reduction Potential & SESD-TP-8201 & NA & $\mathrm{mV}$ \\
\hline 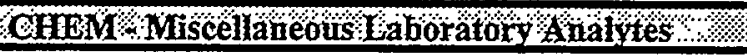 & \%. & \% & \%.।. \\
\hline $\mathrm{pH}$ & EPA-9040 & NA & $\mathrm{pH}$ units \\
\hline Conductivity & EPA-9050 & $\mathrm{NA}$ & $\mu \mathrm{mho} / \mathrm{cm}$ \\
\hline Total Dissolved Solids & EPA-160.1 & 1 & $\mathrm{mg} / \mathrm{L}$ \\
\hline Total Suspended Solids & EPA-160.2 & 1 & $\mathrm{mg} / \mathrm{L}$ \\
\hline Turbidity & EPA-180.1 & 0.1 & NTU \\
\hline CHEM -Anions & $\% \% \% \%$ & & \%.: \\
\hline Alkalinity - HCO3 & EPA-310.1 & 1.0 & $\mathrm{mg} / \mathrm{L}$ \\
\hline Alkalinity - $\mathrm{CO} 3$ & EPA-310.1 & 1.0 & $\mathrm{mg} / \mathrm{L}$ \\
\hline Chloride & EPA-300.0 & 0.2 & $\mathrm{mg} / \mathrm{L}$ \\
\hline Fluoride & EPA-340.2 & 0.1 & $\mathrm{mg} / \mathrm{L}$ \\
\hline Nitrate (as Nitrogen) & EPA-300.0 & 0.028 & $\mathrm{mg} / \mathrm{L}$ \\
\hline Sulfate & EPA-300.0 & 0.25 & $\mathrm{mg} / \mathrm{L}$ \\
\hline 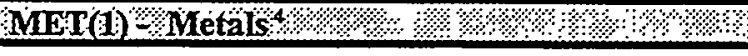 & \% ४ & \%०० & $08 \%$ \\
\hline Aluminum & EPA-6010A & 0.02 & $\mathrm{mg} / \mathrm{L}$ \\
\hline Antimony & EPA-200.8 & 0.005 & $\mathrm{mg} / \mathrm{L}$ \\
\hline Arsenic & EPA-200.8 & 0.005 & $\mathrm{mg} / \mathrm{L}$ \\
\hline Barium & EPA-6010A & 0.001 & $\mathrm{mg} / \mathrm{L}$ \\
\hline Beryllium & EPA-6010A & 0.0003 & $\mathrm{mg} / \mathrm{L}$ \\
\hline Boron & EPA-6010A & 0.004 & $\mathrm{mg} / \mathrm{L}$ \\
\hline Cadmium & EPA-200.8 & 0.0005 & $\mathrm{mg} / \mathrm{L}$ \\
\hline Calcium & EPA-6010A & 0.008 & $\mathrm{mg} / \mathrm{L}$ \\
\hline Chromium & EPA-6010A & 0.01 & $\mathrm{mg} / \mathrm{L}$ \\
\hline Cobalt & EPA-6010A & 0.005 & $\mathrm{mg} / \mathrm{L}$ \\
\hline Copper & EPA-6010A & 0.004 & $\mathrm{mg} / \mathrm{L}$ \\
\hline Iron & EPA-6010A & 0.005 & $\mathrm{mg} / \mathrm{L}$ \\
\hline Lead & EPA-200.8 & 0.0005 & $\mathrm{mg} / \mathrm{L}$ \\
\hline Lithium & EPA-6010A & 0.004 & $\mathrm{mg} / \mathrm{L}$ \\
\hline Magnesium & EPA-6010A & 0.003 & $\mathrm{mg} / \mathrm{L}$ \\
\hline Manganese & EPA-6010A & 0.001 & $\mathrm{mg} / \mathrm{L}$ \\
\hline Mercury & EPA-7470 & 0.0002 & $\mathrm{mg} / \mathrm{L}$ \\
\hline Molybdenum & EPA-6010A & 0.01 & $\mathrm{mg} / \mathrm{L}$ \\
\hline
\end{tabular}


Table 2 (continued)

\begin{tabular}{|c|c|c|c|}
\hline METf I - Wetals (conta) & Ana y tical uéthod? & Detectiond Slmitz & Wuits $3:$ \\
\hline Nickel & EPA-6010A & 0.01 & $\mathrm{mg} / \mathrm{L}$ \\
\hline Potassium & EPA-6010A & 0.6 & $\mathrm{mg} / \mathrm{L}$ \\
\hline Selenium & EPA-200.8 & 0.01 & $\mathrm{mg} / \mathrm{L}$ \\
\hline Silver & EPA-6010A & 0.006 & $\mathrm{mg} / \mathrm{L}$ \\
\hline Sodium & EPA-6010A & 0.02 & $\mathrm{mg} / \mathrm{L}$ \\
\hline Strontium & EPA-6010A & 0.0004 & $\mathrm{mg} / \mathrm{L}$ \\
\hline Thallium & EPA-200.8 & 0.0005 & $\mathrm{mg} / \mathrm{L}$ \\
\hline Thorium & EPA-6010A & 0.2 & $\mathrm{mg} / \mathrm{L}$ \\
\hline Uranium & EPA-200.8 & 0.0005 & $\mathrm{mg} / \mathrm{L}$ \\
\hline Vanadium & EPA-6010A & 0.005 & $\mathrm{mg} / \mathrm{L}$ \\
\hline Zinc & EPA-6010A & 0.002 & $\mathrm{mg} / \mathrm{L}$ \\
\hline 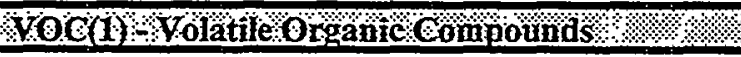 & 1\%. & SCROLF\%: & $3 \%$ \\
\hline Acetone & EPA-8260B & 10 & $\mu \mathrm{g} / \mathrm{L}$ \\
\hline Acrolein & EPA-8260B & 10 & $\mu \mathrm{g} / \mathrm{L}$ \\
\hline Acrylonitrile & EPA-8260B & 10 & $\mu \mathrm{g} / \mathrm{L}$ \\
\hline Benzene & EPA-8260B & 5 & $\mu \mathrm{g} / \mathrm{L}$ \\
\hline Bromochloromethane & EPA-8260B & 10 & $\mu g / L$ \\
\hline Bromodichloromethane & EPA-8260B & 5 & $\mu \mathrm{g} / \mathrm{L}$ \\
\hline Bromoform & EPA-8260B & 5 & $\mu \mathrm{g} / \mathrm{L}$ \\
\hline Bromomethane & EPA-8260B & 10 & $\mu \mathrm{g} / \mathrm{L}$ \\
\hline 2-Butanone & EPA-8260B & 10 & $\mu \mathrm{g} / \mathrm{L}$ \\
\hline Carbon disulfide & EPA-8260B & 5 & $\mu \mathrm{g} / \mathrm{L}$ \\
\hline Carbon tetrachloride & EPA-8260B & 5 & $\mu \mathrm{g} / \mathrm{L}$ \\
\hline Chlorobenzene & EPA-8260B & 5 & $\mu \mathrm{g} / \mathrm{L}$ \\
\hline Chloroethane & EPA-8260B & 10 & $\mu \mathrm{g} / \mathrm{L}$ \\
\hline 2-Chloroethyl vinyl ether & EPA-8260B & 10 & $\mu \mathrm{g} / \mathrm{L}$ \\
\hline Chloroform & EPA-8260B & 5 & $\mu \mathrm{g} / \mathrm{L}$ \\
\hline Chloromethane & EPA-8260B & 10 & $\mu \mathrm{g} / \mathrm{L}$ \\
\hline Dibromochloromethane & EPA-8260B & 5 & $\mu \mathrm{g} / \mathrm{L}$ \\
\hline 1,2-Dibromo-3-chloropropane & EPA-8260B & 10 & $\mu \mathrm{g} / \mathrm{L}$ \\
\hline 1,2-Dibromoethane & EPA-8260B & 5 & $\mu g / L$ \\
\hline Dibromomethane & EPA-8260B & 10 & $\mu \mathrm{g} / \mathrm{L}$ \\
\hline 1,2-Dichlorobenzene & EPA-8260B & 5 & $\mu \mathrm{g} / \mathrm{L}$ \\
\hline 1,4-Dichlorobenzene & EPA-8260B & 5 & $\mu \mathrm{g} / \mathrm{L}$ \\
\hline 1,4-Dichloro-2-butene & EPA-8260B & 5 & $\mu \mathrm{g} / \mathrm{L}$ \\
\hline trans-1,4-Dichloro-2-butene & EPA-8260B & 5 & $\mu \mathrm{g} / \mathrm{L}$ \\
\hline Dichlorodifluoromethane & EPA-8260B & 5 & $\mu \mathrm{g} / \mathrm{L}$ \\
\hline 1,1-Dichloroethane & EPA-8260B & 5 & $\mu \mathrm{g} / \mathrm{L}$ \\
\hline 1,2-Dichloroethane & EPA-8260B & 5 & $\mu \mathrm{g} / \mathrm{L}$ \\
\hline 1,1-Dichloroethene & EPA-8260B & 5 & $\mu \mathrm{g} / \mathrm{L}$ \\
\hline 1,2-Dichloroethene & EPA-8260B & 5 & $\mu \mathrm{g} / \mathrm{L}$ \\
\hline
\end{tabular}


Table 2 (continued)

\begin{tabular}{|c|c|c|c|}
\hline Voc(1) Yolatie Organic Compounds (conta). & Analýticalisuéthod? & अGROU\% & QGinits 3 \\
\hline cis-1,2-Dichloroethene & EPA-8260B & 5 & $\mu \mathrm{g} / \mathrm{L}$ \\
\hline trans-1,2-Dichloroethene & EPA-8260B & 5 & $\mu \mathrm{g} / \mathrm{L}$ \\
\hline 1,2-Dichloropropane & EPA-8260B & 5 & $\mu g / L$ \\
\hline cis-1,3-Dichloropropene & EPA-8260B & 5 & $\mu \mathrm{g} / \mathrm{L}$ \\
\hline trans-1,3-Dichloropropene & EPA-8260B & 5 & $\mu \mathrm{g} / \mathrm{L}$ \\
\hline Dimethylbenzene & EPA-8260B & 5 & $\mu \mathrm{g} / \mathrm{L}$ \\
\hline Ethanol & EPA-8260B & 500 & $\mu \mathrm{g} / \mathrm{L}$ \\
\hline Ethylbenzene & EPA-8260B & 5 & $\mu \mathrm{g} / \mathrm{L}$ \\
\hline Ethyl methacrylate & EPA-8260B & 5 & $\mu \mathrm{g} / \mathrm{L}$ \\
\hline 2-Hexanone & EPA-8260B & 10 & $\mu \mathrm{g} / \mathrm{L}$ \\
\hline Iodomethane & EPA-8260B & 5 & $\mu \mathrm{g} / \mathrm{L}$ \\
\hline 4-Methyl-2-pentanone & EPA-8260B & 10 & $\mu \mathrm{g} / \mathrm{L}$ \\
\hline Methylerie chloride & EPA-8260B & 5 & $\mu \mathrm{g} / \mathrm{L}$ \\
\hline Styrene & EPA-8260B & 5 & $\mu \mathrm{g} / \mathrm{L}$ \\
\hline 1,1,1,2-Tetrachloroethane & EPA-8260B & 10 & $\mu \mathrm{g} / \mathrm{L}$ \\
\hline 1,1,2,2-Tetrachloroethane & EPA-8260B & 5 & $\mu \mathrm{g} / \mathrm{L}$ \\
\hline Tetrachloroethene & EPA-8260B & 5 & $\mu \mathrm{g} / \mathrm{L}$ \\
\hline Toluene & EPA-8260B & 5 & $\mu \mathrm{g} / \mathrm{L}$ \\
\hline 1,1,1-Trichloroethane & EPA-8260B & 5 & $\mu \mathrm{g} / \mathrm{L}$ \\
\hline 1,1,2-Trichloroethane & EPA-8260B & 5 & $\mu \mathrm{g} / \mathrm{L}$ \\
\hline Trichloroethene & EPA-8260B & 5 & $\mu \mathrm{g} / \mathrm{L}$ \\
\hline Trichlorofluoromethane & EPA-8260B & 5 & $\mu \mathrm{g} / \mathrm{L}$ \\
\hline 1,2,3-Trichloropropane & EPA-8260B & 5 & $\mu \mathrm{g} / \mathrm{L}$ \\
\hline Vinyl acetate & EPA-8260B & 10 & $\mu \mathrm{g} / \mathrm{L}$ \\
\hline Vinyl chloride & EPA-8260B & 10 & $\mu \mathrm{g} / \mathrm{L}$ \\
\hline 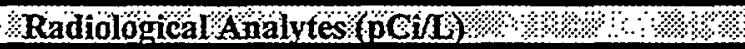 & $8 \% \%$ \% \% & Farget MDA & ४। \\
\hline Gross Alpha Activity & $\mathrm{EPA}-900.0$ & 3.5 & $\mathrm{pCi} / \mathrm{L}$ \\
\hline Gross Beta Activity & $\mathrm{EPA}-900.0$ & 7.0 & $\mathrm{pCi} / \mathrm{L}$ \\
\hline Strontium-89/90 & EPA-905.0 & 4.0 & $\mathrm{pCi} / \mathrm{L}$ \\
\hline $\mathrm{RAD}(2), \operatorname{RAD}(12)$ & Y/P65-7154 & 10 & $\mathrm{pCi} / \mathrm{L}$ \\
\hline $\mathrm{RAD}(2)$ & EPA-906.0 & 300 & $\mathrm{pCi} / \mathrm{L}$ \\
\hline Uranium-234, 235, \& 238 & ACO-TP-7226 & 0.4 & $\mathrm{pCi} / \mathrm{L}$ \\
\hline Americium-241 & ACO-TP-7226 & 0.4 & $\mathrm{pCi} / \mathrm{L}$ \\
\hline Iodine-129 & EPA-901.1 & 3.0 & $\mathrm{pCi} / \mathrm{L}$ \\
\hline Neptunium-237 & Y/P65-7206 & 0.4 & $\mathrm{pCi} / \mathrm{L}$ \\
\hline Plutonium-238 \& 239/240 & ACO-TP-7226 & 0.4 & $\mathrm{pCi} / \mathrm{L}$ \\
\hline Radium-223/224/226 & EPA-903.0-904.0 & 0.5 & $\mathrm{pCi} / \mathrm{L}$ \\
\hline Thorium-228,230,232, \& 234 & Y/P65-7206 & 0.4 & $\mathrm{pCi} / \mathrm{L}$ \\
\hline Total Uranium and weight \% U-235 & Y/P65-8044 & $\overline{N A}$ & $\mathrm{mg} / \mathrm{L}$ \\
\hline
\end{tabular}




\section{Table 2 (continued)}

Notes:

1 Analytical/field methods/procedures from:

- Y-12 Plant System Operation Procedures (LMES 1996c, 1999b, and 1999c)

- Test Methods for Evaluating Solid Waste Physical/Chemical Methods (U.S. Environmental Protection Agency 1996)

- Methods for Chemical Analysis of Water and Wastes (U.S. Environmental Protection Agency 1983)

- Lockheed Martin Energy Systems ACO Control Procedures, radiochemistry (ACO-TP-7226 and Y/P65-7206)

2 NA - not applicable

$3 \mathrm{ft}$ - feet

$\mu \mathrm{g} / \mathrm{L}$ - micrograms per liter

$\mu \mathrm{mho} / \mathrm{cm}$ - micromhos per centimeter

$\mathrm{mg} / \mathrm{L}$ - milligrams per liter

$\mathrm{mV}$ - millivolts

NTU - nephelometric turbidity units

ppm - parts per million

$\mathrm{pCi} / \mathrm{L}$ - picoCuries per liter

$4 \quad$ Filtered samples for dissolved metals analyses will be collected only at specified locations (see Table 1).

5 CRQL - contract-required quantitation limit

6 MDA - minimum detectable activity. The target MDA may be obtained under optimal analytical conditions; actual MDAs are sample-specific and may vary significantly from the target value. 


\section{DISTRIBUTION}

\section{U.S. DEPARTMENT OF ENERGY}

D.G. Adler

J.D. Darby

J.P. Donnelly

M.S. Ferre

ENVIRONMENTAL COMPLIANCE

DEPARTMENT

S.M. Field

S.B. Jones

C.C. Hill

J.E. Powell

E.B. Rundle

L.O. Vaughan

GWPP-File-RC (2)

LOCKHEED MARTIN

ENERGY RESEARCH

R.H. Ketelle

D.B. Watson

Y-12 Central Files

Y-12 Plant Records Services (2) 9711-5,

MS-8169 [2 copies for OSTI]
ANALYTICAL CHEMISTRY ORGANIZATION

D.D. Altom

R. E. Slagle

BECHTEL JACOBS COMPANY LLC

M.L. Allen (2)

C.S. Haase (2)

H.L. King

D.W. McCune

P.F. Waldschlager

File-EMEF-DMC

SCIENCE APPLICATIONS

INTERNATIONAL CORPORATION

D.J. Landers

TENNESSEE DEPARTMENT OF

ENVIRONMENT AND

CONSERVATION -

DOE OVERSIGHT DIVISION

D. Gilmore (3) 